\title{
Some Charophytes from the Middle Dinosaur Member of the Tendaguru Formation (Upper Jurassic of Tanzania)
}

\author{
Michael E. Schudack ${ }^{1}$ \\ With 2 text-figures and 1 plate
}

\begin{abstract}
Biostratigraphy and paleoecology of the famous dinosaur beds of Tendaguru Formation, Tanzania, East Africa are still under discussion. Calcareous microfossils have not yet contributed to this question. Four samples from the Middle Dinosaur Member have now yielded charophyte gyrogonites of the species Aclistochara cf. bransonii, Aclistochara cf. minor, Mesochara canellata, and Mesochara harrisi. Considering ammonite datations in under- and overlying members, even their long stratigrapical ranges point to a Kimmeridgian age for the Middle Dinosaur Member of Tendaguru Formation. Salinity tolerances of the species (if autochthonous) suggest a variable environment with partly brackish, partly freshwater influences.
\end{abstract}

Key words: Upper Jurassic, Tanzania, Tendaguru, Charophyta, biostratigraphy, paleoecology.

\section{Zusammenfassung}

Biostratigraphie und Paläoökologie der berühmten Dinosaurier-Fundschichten am Tendaguru Hill in Tansania (Ostafrika) sind bis heute umstritten. Kalkige Mikrofossilien hatten zu dieser Diskussion bisher nicht beigetragen. In vier Proben aus dem Mittleren Dinosauriermergel fanden sich nun Charophyten-Gyrogonite der Arten Aclistochara cf. bransonii, Aclistochara cf. minor, Mesochara canellata und Mesochara harrisi. Trotz generell langer stratigraphischer Reichweiten dieser Arten macht ihr Vorkommen im Zusammenhang mit Ammonitenfunden in unter- und überlagernden Schichten ein Kimmeridgium-Alter des Mittleren Dinosauriermergels wahrscheinlich, während ihre Salinitätstoleranzen (autochthones Vorkommen vorausgesetzt) auf ein wechselhaftes Milieu mit teils schwach brackischen, teils Süßwassereinflüssen hindeuten.

\section{Introduction}

The Tendaguru Formation is a mixed marine/ nonmarine formation in Southern Tanzania that contains a wealth of freshwater, brackish water, and marine fossils. The formation has originally been called Tendaguru Beds or Tendaguru Series by different authors (Parkinson 1930, Aitken 1961). However, according to the international stratigraphic guidelines of the IUGS, the term "series" should better be restricted to biostratigraphy, whereas the term "bed" is a lithostratigraphic term on a very minor level. Therefore, following the stratigraphic code, the name "Tendaguru Formation" for the whole sequences at issue, and "Members" for the six main stratigraphic intervals (see below) should be used.
The formation is well known for its spectacular dinosaur fauna found during the excavations from 1909 to 1913 ("Deutsche Tendaguru-Expedition", Janensch 1914a) in the vicinity of the Tendaguru hill about $60 \mathrm{~km}$ northwest of the province capital of Lindi (Fig. 1). In the Tendaguru area, the formation is about $140 \mathrm{~m}$ thick (Janensch 1914b), cyclically changing between three predominantly nonmarine (dinosaur marls) and three marine layers. Lithostratigraphic succession of the six members is (from oldest to youngest): Lower Dinosaur Member $\rightarrow$ Nerinea Member $\rightarrow$ Middle Dinosaur Member $\rightarrow$ Smeei Member $\rightarrow$ Upper Dinosaur Member $\rightarrow$ Schwar$z i$ Member (Fig. 2). Names of the two latter marine members are after species of the bivalve Trigonia (see, however, systematic and nomenclatoric revisions by Aitken 1961). Detailed sedi-

\footnotetext{
${ }^{1}$ Institut für Paläontologie der FU Berlin, Malteserstraße 74-100, 12249 Berlin, Germany.

Email: schudack@zedat.fu-berlin.de

Received February 1999, accepted June 1999
} 


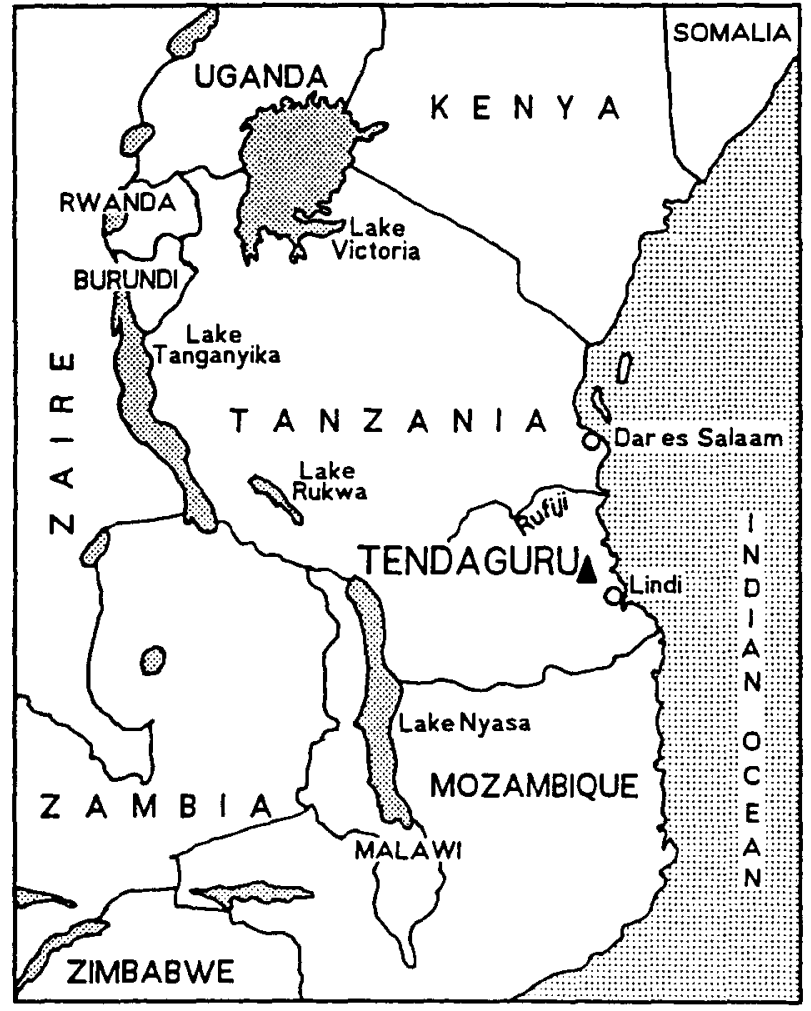

Fig. 1. Geographical situation of Tendaguru Hill, Tanzania. Original figure from Zils et al. (1995)

mentologic and stratigraphic descriptions of these members are in Janensch (1914b), Aitken (1961), Zils et al. (1995) and others.

The age of the different members of the Tendaguru Formation is still under discussion. For the three Dinosaur members (Fig. 2), there is no direct biostratigraphic datation yet, except for the fact, that much of the vertebrate fauna is very similar to dinosaurs from the Morrison Formation in the U.S. Western Interior, which is Kimmeridgian to Lower Tithonian in age (Schudack 1995, Schudack et al. 1998, Kowallis et al. 1998, Litwin et al. 1998). There are, however, also some genera which have, apart from Tendaguru, yet only been found in Lower Cretaceous formations of other parts of Africa (Lapparent 1960). The study of a microflora from the Upper Dinosaur Member has not allowed decision between a late Jurassic or early Cretaceous age (Jarzen 1981).

Biostratigraphy of the marine members (Fig. 2) has hitherto been depending only on macro-invertebrates such as ammonites and bivalves (mostly Trigonia). However, very different ages have been suggested: Oxfordian (Zwierczycki 1914, Behrendt 1918), Oxfordian to Kimmeridgian (Dietrich 1927), Lower to Middle Kimmeridgian (Dietrich 1925) or Middle to Upper Kimmeridgian (Aitken 1961) for the Nerinea

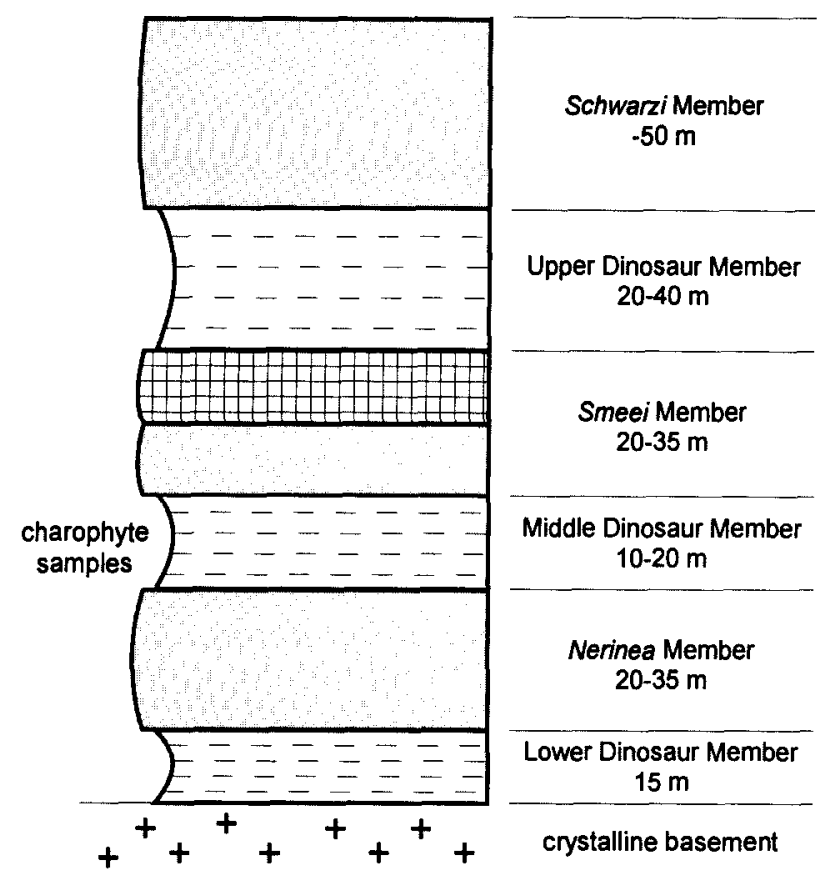

Fig. 2. Principal lithostratigraphic succession of the Tendaguru Formation in the vicinities of Tendaguru Hill, Tanzania. Simplified after Hennig (1937) and Zils et al. (1995)

Member, Middle to Upper Kimmeridgian (Hennig 1937), Upper Kimmeridgian to Tithonian (Zwierczycki 1914, Behrendt 1918, Dietrich 1925, Aitken 1961) or Tithonian (Lange 1914) for the Smeei Member. The Schwarzi Member (top of the formation), under general agreement and due to its relative richness in ammonites even in the Tendaguru vicinity, is already early Cretaceous in age (Zwierczycki 1914, Aitken 1961). More recently, Zils et al. (1995), based on new ammonite findings from the western slope of Tendaguru hill, have suggested an Oxfordian age for the Nerinea Member and a Kimmeridgian age for the Smeei Member. If the latter datations are correct, the Middle Dinosaur Member must be Oxfordian or Kimmeridgian in age, but can not be younger (i.e. Tithonian or even Berriasian, see below).

The paleoecology of the dinosaur members is also under controverse discussion. Several authors have suggested an estuarine environment with mixed marine/brackish water/freshwater conditions (e.g. Abel 1927, Parkinson 1930), whereas others assumed environments such as a shallow lagoon separated from the open sea by coral reefs, with periodical freshwater influxes (Janensch 1914b, Dietrich 1933), or even a hypersaline, periodically evaporating lagoon (Reck 1925).

Calcareous microfossils such as foraminifera, ostracods, and charophytes have only been mentioned in very few papers (Dietrich 1925, Zils 
et al. 1995), but they have not been used for biostratigraphical or paleoecological purposes so far.

\section{Material and methods}

The material presented here is from four isolated samples from the Middle Dinosaur Member of the Tendaguru Formation of Tendaguru hill area (see Janensch 1914b). It is all from the excavations of the "Deutsche Tendaguru-Expedition" of 1909 to 1913 (Janensch 1914a). Some of these samples have originally been taken for sedimentological studies, whereas others are just remains of sediment still resting on dinosaur bones in the collections of the Naturkundemuseum Berlin, gratefully made available by Dr. W.-D. Heinrich. Dr. E. Pietrzeniuk (also Naturkundemuseum Berlin) and her team have processed the samples (standard method using hydrogen peroxide) and picked out the fossils. SEM fotos have been made with a Cambridge S 360 .

Sample numbers and localities are: 11-190 (locality WJ south of Kindope), 11-307 ("Cyrena marls"), 11-308 (locality WJ 3007), and 11-351 (Kitukikituki). Origin of most of the samples does not allow any more detailed horizonting within the Middle Dinosaur Member. Hopefully more material including more numerous populations will be available in the near future, in order to allow more detailed stratigraphic and paleoecologic conclusions.

\section{Results}

The four samples have yielded the following charophytes (Charophyceae G. M. Smith emend. Schudack, 1993):

Sample 11-190: Mesochara canellata and Mesochara harrisi

Sample 11-307: Mesochara harrisi

Sample 11-308: Aclistochara cf. bransonii

Sample 11-351: Aclistochara cf. minor, Mesochara canellata and Mesochara harrisi

\section{Systematic descriptions}

Aclistochara Peck emend. Schudack, 1993 (Porocharaceae Grambast emend. Schudack, 1993)

Aclistochara cf. bransonii Peck, 1937

(Pl. 1, fig. 1)

Description: see Schudack (1993: 59-60).

Variation: Length $315 \mu \mathrm{m}$, width $300 \mu \mathrm{m}$, length/width ratio 1.05 , number of convolutions 9, width of spiral cells $35 \mu \mathrm{m}$.

Material: 1 gyrogonite.

Occurrence: Sample 11-308.

Other occurences (after Schudack 1996a): Late Oxfordian to Berriasian of Germany and
Switzerland, late Jurassic of China, Kimmeridgian of Mongolia, Tithonian of Russia, Kimmeridgian of the Western US.

Ecology (after Schudack 1996b): Slightly salinity tolerant, but mainly in freshwater.

Aclistochara cf. minor Schudack, 1990

(Pl. 1, fig. 2)

Description: see Schudack (1993: 60).

Variation: Length $205 \mu \mathrm{m}$, width $190 \mu \mathrm{m}$, length/width ratio 1.08 , number of convolutions 9, width of spiral cells $25 \mu \mathrm{m}$.

Material: 1 gyrogonite.

Occurrence: Sample 11-351.

Other occurences (after Schudack 1996a): Kimmeridgian to Berriasian of Germany.

Ecology (after Schudack 1996b): Halophobe species, almost exclusively in freshwater.

Mesochara Grambast, 1962 (Characeae Richard ex C. Agardh emend. Martin-Closas \& Schudack, 1991)

Mesochara canellata (Mädler, 1952) Shaikin, 1967

(Pl. 1, fig. 3-4)

Description: see Schudack (1993: 62-63).

Variation: Length $230-270 \mu \mathrm{m}$, width $200-230 \mu \mathrm{m}$, length/width ratio $1.13-1.17$, number of convolutions $7-9$, width of spiral cells $25-30 \mu \mathrm{m}$.

Material: 8 gyrogonites.

Occurrence: Samples 11-190 and 11-351.

Other occurences (after Schudack 1996a): Kimmeridgian to Berriasian of Germany.

Ecology (after Schudack 1996b): Slightly salinity tolerant, but mainly in freshwater.

Mesochara harrisi (Mädler, 1952) Shaikin, 1967

(Pl. 1, fig. 5-8)

Description: see Schudack (1993: 63-64).

Variation: Length $320-410 \mu \mathrm{m}$, width 275 $315 \mu \mathrm{m}$, length/width ratio $1.13-1.49$, number of convolutions $8-10$, width of spiral cells $35-45 \mu \mathrm{m}$.

Material: 20 gyrogonites.

Occurrence: Samples 11-190, 11-307 and 11351.

Other occurences (after Schudack 1996a): Late Oxfordian to Berriasian of Germany, Kim- 


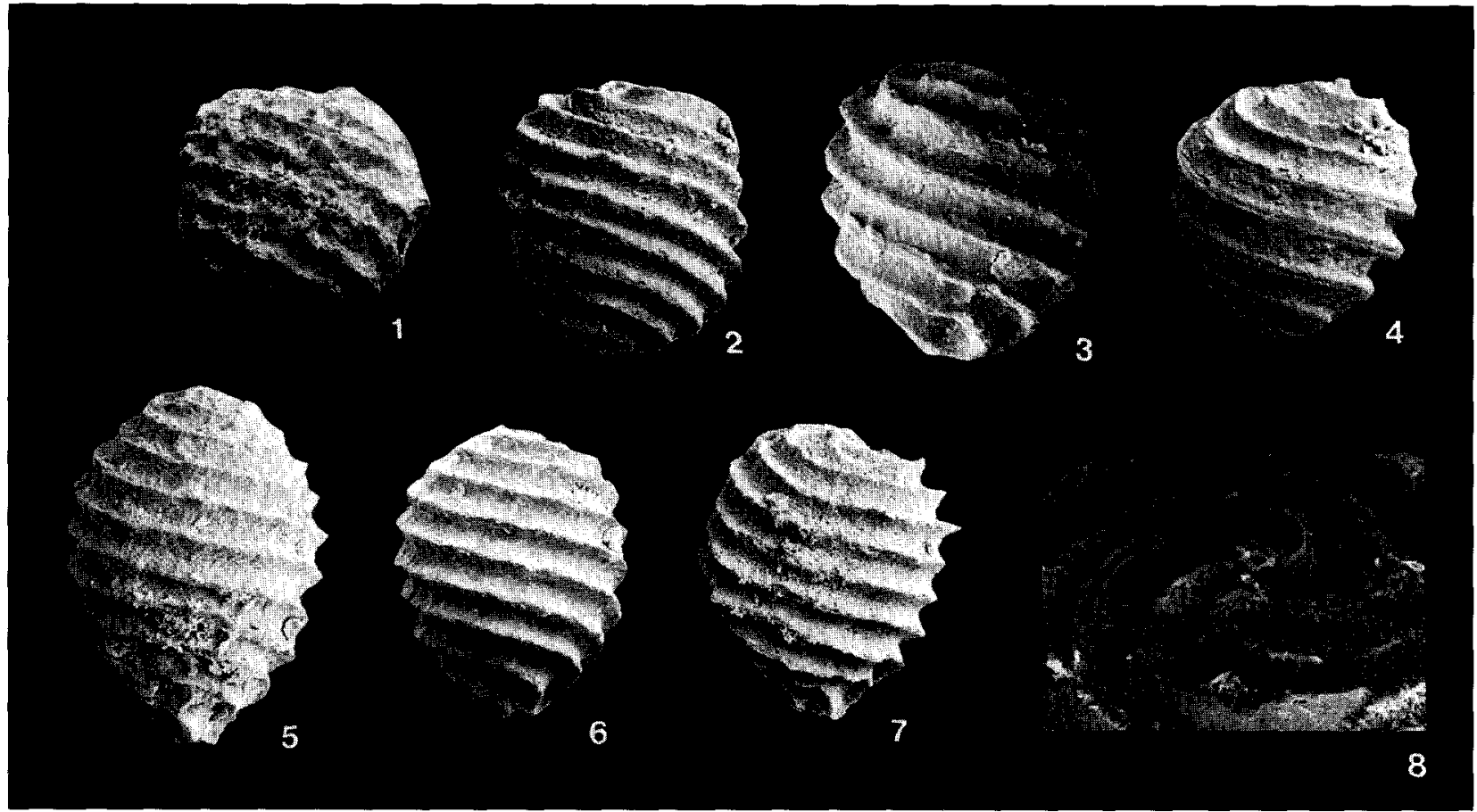

Plate 1. Charophytes from the Middle Dinosaur Member of Tendaguru Formation, Tanzania. Fig. 1: Aclistochara cf. bransonii, length $315 \mu \mathrm{m}$, sample 11-308. Fig. 2: Aclistochara cf. minor, length $205 \mu \mathrm{m}$, sample 11-351. Fig. 3-4: Mesochara canellata. Fig. 3: length $235 \mu \mathrm{m}$, sample 11-190. Fig. 4: length $240 \mu \mathrm{m}$, sample 11-190. Fig. 5-8: Mesochara harrisi. Fig. 5: length $340 \mu \mathrm{m}$, sample 11-190. Fig. 6: length $320 \mu \mathrm{m}$, sample 11-190. Fig. 7: length $330 \mu \mathrm{m}$, sample 11-307. Fig. 8: oblique apical view of closed summit, width of figure $170 \mu \mathrm{m}$, sample 11-190

meridigan to Barremian of Spain, Berriasian of France, Kimmeridigan to Tithonian of Russia, early and late Cretaceous of China.

Ecology (after Schudack 1996b): Slightly salinity tolerant, but mainly in freshwater.

\section{Conclusions}

\section{Biostratigraphy:}

Based upon marine macro-invertebrate studies of material from the underlying Nerinea Member and the overlying Smeei Member (Zwierczycki 1914, Aitken 1961, Zils et al. 1995), the possible age of the Middle Dinosaur Member of Tendaguru Formation has been restricted to the Oxfordian or Kimmeridgian stages (see above). Known stratigraphical ranges of charophyte species (nominal species for Aclistochara) described in this paper are:

- Late Oxfordian to Berriasian for Aclistochara bransonii

- Kimmeridgian to Berriasian for Aclistocha minor

- Kimmeridgian to Berriasian for Mesochara cannellata

- Late Oxfordian to late Cretaceous for Mesochara harrisi
From these long ranges, a refined biostratigraphic dating can not be derived. Considering the ammonite findings cited above, however, a Kimmeridgian age of the Middle Dinosaur member seems most probable.

Paleoecology:

Based on the charophyty flora alone, paleosalinity assumptions for the four samples are:

- Sample 11-190: Freshwater or slightly brackish water

- Sample 11-307: Freshwater or slightly brackish water

- Sample 11-308: Freshwater or slightly brackish water

- Sample 11-351: Freshwater

In consequence, the charophytes, if not allochthonous, point to freshwater or - at the maximum - slightly brackish water conditions. However, gyrogonites can easily be transported over long distances, and thus be brought to a lagoonal or estuarine environment from the less saline waters they originally lived in. Ostracods found in the same samples (paper in prep. in cooperation with E. Pietrzeniuk, Humboldt University of Berlin) also point to a predominantly nonmarine or slightly brackish environment but 
the taxononmy of some badly preserved and possibly marine specimens is still under discussion.

\section{Biogeography:}

Biogeographical relationships of the Tendaguru charophyte flora detected so far seem to be stronger with Central and Western Europe (all four species are common to both areas) than with the Morrison Formation in the U.S. Western Interior (Schudack 1996c, Schudack et al. 1998). However, these data are only based on very few samples and specimens and should not be overestimated at the present state of research.

\section{References}

Abel, O. 1927. Lebensbilder der Vorzeit. 637 pp., Jena.

Aitken, W. G. 1961. Geology and Palaeontology of the Jurassic and Cretaceous of Southern Tanganyika. - Geological Survey of Tanganyika Bulletin 31: 1-144.

Behrend, F. 1918. Die Stratigraphie des östlichen Zentralafrika unter Berücksichtigung der Beziehungen zu Südafrika. - Beiträge zur geologischen Erforschung der Deutschen Schutzgebiete 15: $1-148$.

Dietrich, W. O. 1925. Über eine dem mittleren Sauriermergel am Tendaguru äquivalente, rein marine Kimmeridgebildung in Mahokondo, Deutsch-Ostafrika. - Palaeontographica, Supplement 7 (2), 1, 1: 1-24.

- 1927. Das Alter der Trigonienschichten am Tendaguru. Centralblatt für Mineralogie, Geologie und Paläontologie B 2: $59-64$.

- 1933. Zur Stratigraphie und Palaeontologie der Tendaguruschichten. - Palaeontographica, Supplement 7 (2), 2, 1: $1-86$.

Hennig, E. 1937. Der Sedimentstreifen des Lindi-Kilwa-Hinterlandes. - Palaeontographica, Supplement 7 (2), 2, 2: 99-186.

Janensch, W. 1914a. Bericht über den Verlauf der Tendaguru-Expedition. - Archiv für Biontologie 3, 1, 1: 17-58.

- 1914b. Die Gliederung der Tendaguru-Schichten im Tendaguru-Gebiet und die Entstehung der Saurier-Lagerstätten. - Archiv für Biontologie 3, 3, 2: 227-261.

Jarzen, D. M. 1981. A preliminary report of the palynomorphs recovered from Tendaguru hill (Tanzania). - Pollen et Spores 23: 149-163.
Kowallis, B. J., Christiansen, E. H., Deino, A. L., Peterson, F., Turner, C. E., Kunk, M. J. \& Obradovich, J. D. 1998. The age of the Morrison Formation. - Modern Geology 22: $235-260$.

Lange, E. 1914. Die Brachiopoden, Lamellibranchiaten und Anneliden der Trigonia Schwarzi-Schichten. - Archiv für Biontologie 3, 4, 3: 187-289.

Lapparent, A. F. de 1960. Les dinosauriens du "Continental intercalaire" du Sahara central. - Memoire de la Société géologique de France 88A: $1-57$.

Litwin, R. J., Turner, C. E. \& Peterson, F. 1998. Palynological evidence on the age of the Morrison Formation, Western Interior U.S. - Modern Geology 22: 297-319.

Martin-Closas, C. \& Schudack, M. 1991. Phylogenetic analysis and systematization of post-Paleozoic charophytes. Bulletin de la Société botanique de France, 138, Actualités botaniques 1: 53-71.

Parkinson, J. 1930. The dinosaurs in East Africa. An account of the giant reptile beds of Tendaguru, Tanganyika Territory. 192 pp., London.

Reck, H. 1925. Grabungen auf fossile Wirbeltiere in Ostafrika. - Geologische Charakterbilder 31: 1-36.

Schudack, M. 1993. Die Charophyten in Oberjura und Unterkreide Westeuropas. Mit einer phylogenetischen Analyse der Gesamtgruppe. - Berliner geowissenschaftliche Abhandlungen E 8: 1-209.

- 1995. Neue mikropaläontologische Beiträge (Ostracoda, Charophyta) zum Morrison-Ökosystem (Oberjura des Western Interior, USA). - Berliner geowissenschaftliche Abhandlungen E 9: 283-291.

- 1996a. Charophyten des Kimmeridgium, Tithonium und Berriasium aus Bohrungen in Mecklenburg und Brandenburg (Nordostdeutschland). - Hallesches Jahrbuch für Geowissenschaften 18: 153-170.

- 1996b. Die Charophyten des Niedersächsischen Beckens (Oberjura - Berriasium): Lokalzonierung, überregionale Korrelation und Palökologie. - Neues Jahrbuch für Geologie und Paläontologie, Abhandlungen 200: 27-52.

- 1996c. Ostracode and charophyte biogeography in the continental Upper Jurassic of Europe and North America as influenced by plate tectonics and paleoclimate. - Museum of Northern Arizona Bulletin 60: 333-342.

Schudack, M., Turner, C. E. \& Peterson, F. 1998. Biostratigraphy, paleoecology, and biogeography of charophytes and ostracodes from the Upper Jurassic Morrison Formation, Western Interior, U.S.A. - Mcdern Geology 22: $379-414$.

Zils, W., Werner, C., Moritz, A. \& Saanane, C. 1995. Orientierende Tendaguru-Expedition 1994. - Berliner geowissenschaftliche Abhandlungen E 16: 483-531.

Zwierzycki, J. 1914. Die Cephalopodenfauna der TendaguruSchichten in Deutsch-Ostafrika. - Archiv für Biontologie 3 (4): 7-96. 